\title{
Academic Library Buildings: Needs, Legislation, Inventory
}

BY THEODORE SAMORE

\section{NEEDS}

IT Is AXIomatic that the need for physical facilities for academic libraries on our campuses is as great as the need for academic library materials. The two are inseparable. Library materials must be adequately housed if they are to be both conserved and made readily accessible. Also, library quarters must be ample enough so that materials may be efficiently processed and so that students and faculty will find sufficient room to make possible the full use of library materials.

In its Standards for College Libraries (1959), the American Library Association established the following minimum requirements for college library buildings:

1. Accommodations for at least onethird of the student body are essential and twenty-five square feet per student should be made available. In general, the seating capacity of a new building should be based on the anticipated enrollment over a twenty-year period.

2. Staff work areas should comprise
Mr. Samore is College and University Library Specialist, Library Services Branch, U.S. Office of Education.

at least 125 square feet of floor space for each person, and provision should be made for future expansion of staff.

3. Shelf space in a new building should be planned to allow at least for a doubling of the collection.

Libraries can demonstrate their urgent need for more adequate physical facilities by measuring present space with standards recommended by ALA. They can also show the need by appealing to the inevitable increases in student enrollment and number of volumes required.

Table 1 indicates that the serious lag in the construction of library facilities can be demonstrated on the bases of (1) actual and projected enrollments, (2) actual and projected number of volumes. For example, the $\$ 139,000,000$ of library construction planned by educational institutions for the school year ending 1968

TABLE 1

Project Cost of New Library Construction and Rehabilitation Projects Planned by All ACademic Institutions Compared with Projected EnRollment and Volumes AdDED to Library, Aggregate UnIted States:1963-64 to 1967-68 (in millions).

\begin{tabular}{|c|c|c|c|c|c|c|c|}
\hline \multirow{2}{*}{\multicolumn{3}{|c|}{$\begin{array}{c}\text { ScHoOL } \\
\text { YEAR } \\
\text { ENDING }\end{array}$}} & \multirow{2}{*}{ ENROLLMENT } & \multirow{2}{*}{$\begin{array}{l}\text { NEW volumes } \\
\text { ADDED TO } \\
\text { LIBRARY }\end{array}$} & \multicolumn{2}{|c|}{ FACILITIES } & \multirow{2}{*}{$\begin{array}{c}\text { Dollar } \\
\text { GAP }\end{array}$} \\
\hline & & & & & Planned & Needed & \\
\hline $\begin{array}{l}1964 \\
1965 \\
1966 \\
1967 \\
1968\end{array}$ & $\therefore$ & . & $\begin{array}{l}4.6 \\
4.9 \\
5.4 \\
5.8 \\
6.2\end{array}$ & $\begin{array}{l}13.5 \\
15.6 \\
17.8 \\
20.3 \\
22.5\end{array}$ & $\begin{array}{r}\$ 90.0 \\
104.2 \\
122.5 \\
120.6 \\
138.8\end{array}$ & $\begin{array}{r}\$ 145.0 \\
202.0 \\
200.0 \\
215.0 \\
260.0\end{array}$ & $\begin{array}{r}\$ 55.0 \\
97.8 \\
77.5 \\
94.4 \\
121.2\end{array}$ \\
\hline
\end{tabular}

SoURCE: Enrollment data are from U.S. Office of Education projections; volume data are derived from the annual Office of Education publication, Library Statistics of Colleges and Universities. Projections in columns 3-6 by author. 
TABLE 2

Actual and Projected Costs of New LIBRARY CONSTRUCTION AND REHABILITATION Projects By All ACADEMIC Institutions Compared with Actual and Projected Costs of Total ACADEMIC BUILDINGS CONSTRUCTION AND REHABILITATION Projects; Aggregate United States, REPORTED DATA FOR SCHOOL YEARS ENDING 1957-62; ESTIMATES FOR SCHOOL YEARS ENDING 1963-68 (in millions of dollars).

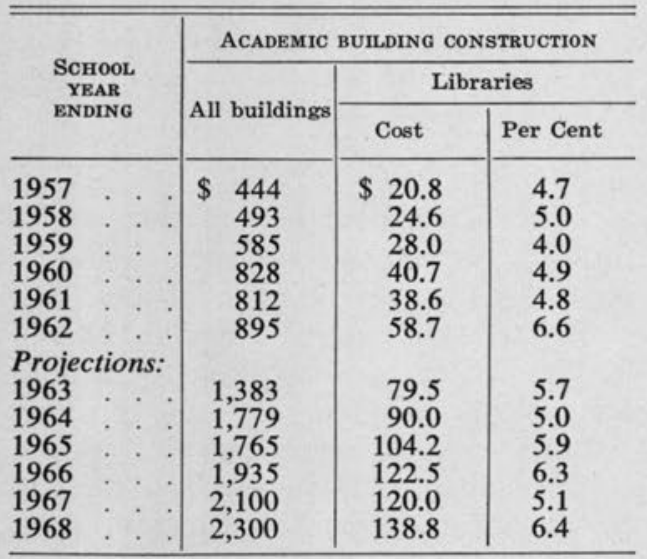

SOURCE: U.S. Department of Health, Education, and Welfare; Office of Education; Proggress in the Construction of Higher Education Facilities, 1951-59 (OE 51002, 1962); New Construction and Rehabilitation on College Campuses, 1959-60 (OE 51002-61, 1963); and College and University Facilities Survey (OE 51000, 1960).

is 53 per cent less than the total amount needed.

These figures were computed chiefly on the bases of fifteen volumes per square foot and seating stations for 16.2 per cent of the increase in student enrollment at twenty-five square feet per station. ${ }^{1}$ The principle that libraries should be built with room enough for fifteen to twenty years growth in volumes and students was also taken into account. Costs were then computed at $\$ 25$ per square foot.

Table 2 shows that the construction of libraries in all institutions of higher edu-

\footnotetext{
116.2 per cent was used because that was the number of students enrolled in Fall 1957 who could be seated at one time in higher education library reading rooms. Library Facilities Planning Aids (OE51004-3), p.1.
}

cation was almost $\$ 39$ million in the school year ending 1961 and may rise to $\$ 139$ million in the school year ending 1968. As a part of total academic library building construction, academic library construction is expected to rise from 4.8 per cent to 6.4 per cent during the same period. The sums for the school years ending 1963-66 in columns 2 and 3 are based on reports of planned construction projects submitted to the Office of Education by institutions of higher education; the sums for the school years ending 1967-68 are projections by the author based on trend.

Additional evidence of urgency is based on data collected by the ALA in a February 1963 survey of academic library building needs. Approximately eight hundred and fifty questionnaires were mailed to all institutions of higher education in the following sixteen states: Arkansas, California, Georgia, Indiana, Kentucky, Louisiana, Massachusetts, Minnesota, Missouri, New Jersey, North Carolina, Ohio, Oregon, Pennsylvania, Rhode Island, and Washington. By March 1 about two-fifths (340) of the questionnaires were returned and usable. Highlights from that survey suggest that:

1. More than one-fourth of the academic library buildings were constructed before 1923; almost half dated from 1942 , but several buildings are over one hundred years old. The library buildings of public academic institutions (other than universities) are significantly more recent than those in private institutions. (Table 3.)

2. However, due to lack of funds or similar reasons, over 40 per cent of public institutions and almost 70 per cent of private institutions indicated that their building plans were more "wishful" than probable.

3. The estimated cost per square foot of construction varies widely-the lowest was $\$ 10$; the highest, $\$ 53$. The estimated median costs for various types of 
TABLE 3

Age of Academic Library Buildings of Selected Institutions in Sixteen States, MarCh 1963*

\begin{tabular}{|c|c|c|c|c|c|c|c|c|c|}
\hline INSTITUTIONS & & & YEAR OF CONS & RUCTION O & LIBRAF & BUILI & NGS & & \\
\hline \multirow[b]{2}{*}{ Type } & \multirow[b]{2}{*}{$\begin{array}{l}\text { Number } \\
\text { reporting }\end{array}$} & \multirow[b]{2}{*}{ Median } & \multirow[b]{2}{*}{ Range } & \multicolumn{6}{|c|}{ Per cent } \\
\hline & & & & $\begin{array}{c}\text { Prior to } \\
1923\end{array}$ & $\underset{32}{1923-}$ & $\underset{42}{1933-}$ & $\begin{array}{c}1943- \\
52\end{array}$ & $\begin{array}{c}1953- \\
62\end{array}$ & Total \\
\hline Total, Public \& Private & 423 & & & & & & & & \\
\hline $\begin{array}{l}\text { Public: } \\
\text { Universities }\end{array}$ & 140 & & & & & & & & \\
\hline $\begin{array}{l}\text { Universities } \\
\text { Liberal arts }\end{array}$ & 27 & 1941 & $1902-1963$ & 17 & 17 & 14 & 14 & 38 & 100 \\
\hline Liberal arts & 25 & $\begin{array}{l}1958 \\
1051\end{array}$ & $1928-1963$ & $\begin{array}{l}4 \\
0\end{array}$ & 4 & 17 & 11 & 64 & 100 \\
\hline Teachers colleges & $\begin{array}{r}29 \\
5\end{array}$ & $\begin{array}{l}1951 \\
1953\end{array}$ & $\begin{array}{l}1855-1963 \\
1935-1960\end{array}$ & 9 & 11 & 23 & & 42 & 100 \\
\hline Junior colleges & 54 & 1956 & $\begin{array}{l}1935-1960 \\
1872-1963\end{array}$ & 7 & 4 & 20 & $\begin{array}{l}14 \\
11\end{array}$ & 80 & 100 \\
\hline Private: & 283 & & & & & & & & 100 \\
\hline Universities & 20 & 1940 & $1877-1963$ & 22 & 26 & 14 & 19 & 19 & 100 \\
\hline Liberal arts . & 183 & 1944 & $1873-1963$ & 18 & 16 & 11 & 16 & 39 & 100 \\
\hline Teachers colleges & 4 & 1948 & $1936-1952$ & & & 25 & 75 & & 100 \\
\hline Technological . . & 4 & 1923 & $1919-1963$ & 20 & 20 & 20 & 20 & 20 & 100 \\
\hline Theological & 31 & 1950 & $1860-1963$ & 36 & 4 & 4 & 13 & 43 & 100 \\
\hline Other prof. schools & 12 & 1937 & 1925-1954 & & 39 & 30 & 8 & 23 & 100 \\
\hline Junior colleges . . & 29 & 1930 & $1872-1963$ & 35 & 17 & & 16 & 32 & 100 \\
\hline
\end{tabular}

- A number of institutions reported more than one date as the age of the building; as a result, percentages in several instances are based on greater numbers than indicated in the "number reporting" column.

construction ranged from $\$ 17$ to $\$ 26$ per square foot.

4. Planned construction in usable space totals nearly five million square feet, about evenly divided between public and private institutions.

5. As Table 4 indicates, by 1970 public academic libraries will need to more than double their physical space, substantially more than double their seating capacity, and almost double their volume capacity. Except in volume capacity, almost the same holds true for private academic libraries.

\section{LEgisLATION}

Congress recognized the need for aid to higher education by passing the Higher Education Facilities Act of 1963 (P.L. 88-204) in December. Among other things, federal funds are now available for the construction of classrooms, laboratories and libraries. In brief, the Act: ${ }^{2}$

1. Establishes a five-year program of grants to institutions of higher education

\footnotetext{
' See the January-February 1964 issue of Higher Education for a detailed section-by-section analysis.
}

for the construction of academic facilities, to be administered by the Commissioner of Education. It authorizes appropriations of $\$ 230,000,000$ annually for fiscal 1964, 1965, and 1966 (see Table 5). Twenty-two per cent of the funds ( $\$ 152$,000,000 for 1964 through 1966) are reserved for public community colleges and technical institutes. The federal share of grants to public community colleges and public technical institutes will be 40 per cent of the development cost. The funds are allotted among the states on the basis of relative number of high school graduates and state allotment formulas based on per capita income. (See Table 6.)

The remaining 78 per cent ( $\$ 538$ million) will be used in providing academic facilities for all other private and public institutions of higher education (except theological schools and schools for the health professions). These funds may be used only for structures or portions thereof, especially designed for instruction or research in the natural or physical sciences, engineering, mathematics, modern foreign languages, and for libraries. Half 
TABLE 4

Academic Library Space of Selected Institutions in Sixteen States, March 1963 (in thousands).

\begin{tabular}{|c|c|c|c|c|c|c|c|c|c|}
\hline \multirow{2}{*}{$\begin{array}{c}\text { TYPE OF } \\
\text { INSTITUTION }\end{array}$} & \multicolumn{3}{|c|}{ USABLE SPACE (SQUARE FEET) } & \multicolumn{3}{|c|}{ SEATING CaPACity } & \multicolumn{3}{|c|}{ Shelving capacity (Volumes) } \\
\hline & Present* & 1970 & Needed & Present* & 1970 & Needed & Present* & 1970 & Needed \\
\hline All Institutions & 12,044 & 23,242 & 11,195 & 152.5 & 321.2 & 168.7 & 68,369 & 109,809 & 40,744 \\
\hline Public: & 5,714 & 12,258 & 6,543 & 75.7 & 180.1 & 104.4 & 25,220 & 48,100 & 21,880 \\
\hline Universities & 2,738 & 5,681 & 2,942 & 27.3 & 68.2 & 40.9 & 15,335 & 26,002 & 10,667 \\
\hline Liberal arts & 1,373 & 2,979 & 1,606 & 23.2 & 49.9 & 26.7 & 4,590 & 9,664 & 4,074 \\
\hline Teachers . & 767 & 1,942 & 1,175 & 11.0 & 31.1 & 20.1 & 2,879 & 5,786 & 2,907 \\
\hline $\begin{array}{l}\text { Technolog- } \\
\text { ical }\end{array}$ & 149 & 284 & 135 & 1.4 & 3.5 & 2.1 & 657 & 1,205 & 548 \\
\hline $\begin{array}{l}\text { Junior } \\
\text { colleges }\end{array}$ & 687 & 1,372 & 685 & 12.8 & 27.4 & 14.6 & 1,759 & 5,443 & 3,684 \\
\hline Private: & 6,330 & 10,984 & 4,652 & 76.8 & 141.1 & 64.3 & 43,149 & 61,709 & 18,864 \\
\hline Universities & 2,310 & 4,304 & 1,994 & 22.9 & 42.7 & 19.8 & 19,153 & 28.103 & 8,950 \\
\hline Liberal arts & 3,400 & 5,683 & 2,283 & 44.2 & 82.3 & 38.1 & 19,915 & 28,234 & 8,319 \\
\hline Teachers. & 17 & 41 & 23 & .4 & 1.0 & .6 & 123 & 223 & 97 \\
\hline $\begin{array}{c}\text { Technolog- } \\
\text { ical }\end{array}$ & 33 & 68 & 35 & .8 & 1.9 & 1.1 & 178 & 422 & \\
\hline Theological & 351 & $\begin{array}{r}00 \\
413\end{array}$ & 62 & 4.4 & 5.2 & .8 & 2,408 & 2,935 & $\begin{array}{l}244 \\
527\end{array}$ \\
\hline Other prof. & 77 & 194 & 117 & 1.3 & 3.1 & 1.8 & 324 & 744 & 419 \\
\hline $\begin{array}{l}\text { Junior } \\
\text { colleges }\end{array}$ & 142 & 281 & 138 & 2.8 & 4.9 & 2.1 & 1,048 & 1,048 & 308 \\
\hline
\end{tabular}

* March 1963. 


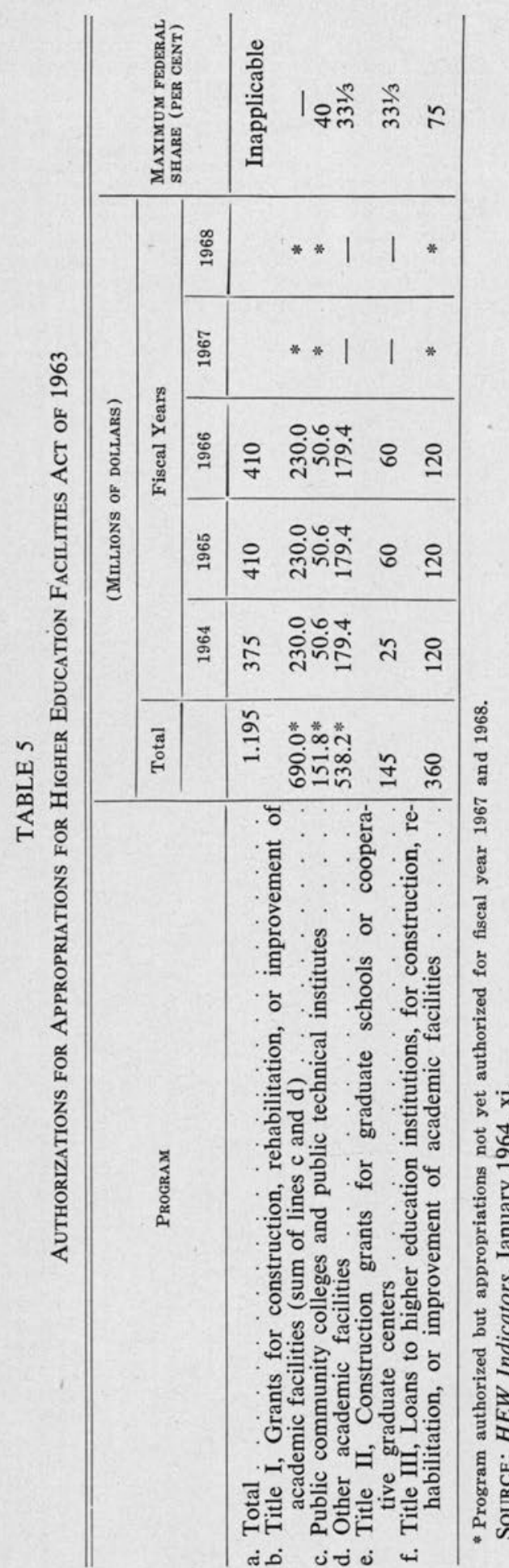

of these funds are allotted among the states on the basis of relative numbers of each state's high-school enrollment (grades 9-12); and half on each state's relative college and university enrollment. The federal share of construction grants may not exceed $331 / 3$ per cent. (See Table 6.)

A state commission designated by each state will determine relative priorities of eligible projects within the state for undergraduate academic facilities and set the federal share as indicated above. This state commission is not responsible for action under Title II.

2. Title II of the Act authorizes grants for construction of graduate academic facilities of $\$ 25,000,000$ for fiscal year 1964 , and $\$ 60,000,000$ for fiscal years 1965 and 1966. The grants are to improve existing graduate schools and to assist in establishment of graduate schools and cooperative graduate centers of excellence. There is no allotment formula for funds under Title II, but payments made to institutions in any one state may not exceed $12 \frac{1}{2}$ per cent of the appropriation. Grants may not exceed $331 / 3$ per cent of the cost of any project. An Advisory Committee on Graduate Education will advise the U.S. Commissioner of Education on policies, procedures, and applications for graduate academic facilities construction grants. The membership shall consist of the Commissioner (chairman), one representative from the office of Science and Technology in the Executive Office of the President, one from the $\mathrm{Na}$ tional Science Foundation, and eight additional members appointed by the Commissioner with the approval of the Secretary of Health, Education, and Welfare.

3. Title III of the Act authorizes loans for construction of academic facilities, both undergraduate and graduate, in the amount of $\$ 120,000,000$ for each of fiscal years 1964, 1965, and 1966 . There is no allotment formula for funds under Title III, but loans made to institutions in any one state may not exceed $12 \frac{1}{2}$ per 
TABLE 6

Grants for Construction of Undergraduate Academic Facilities: by States, Fiscal Year 1964, Authorized by the Higher Education Facilities ACt of 1963, Title 1

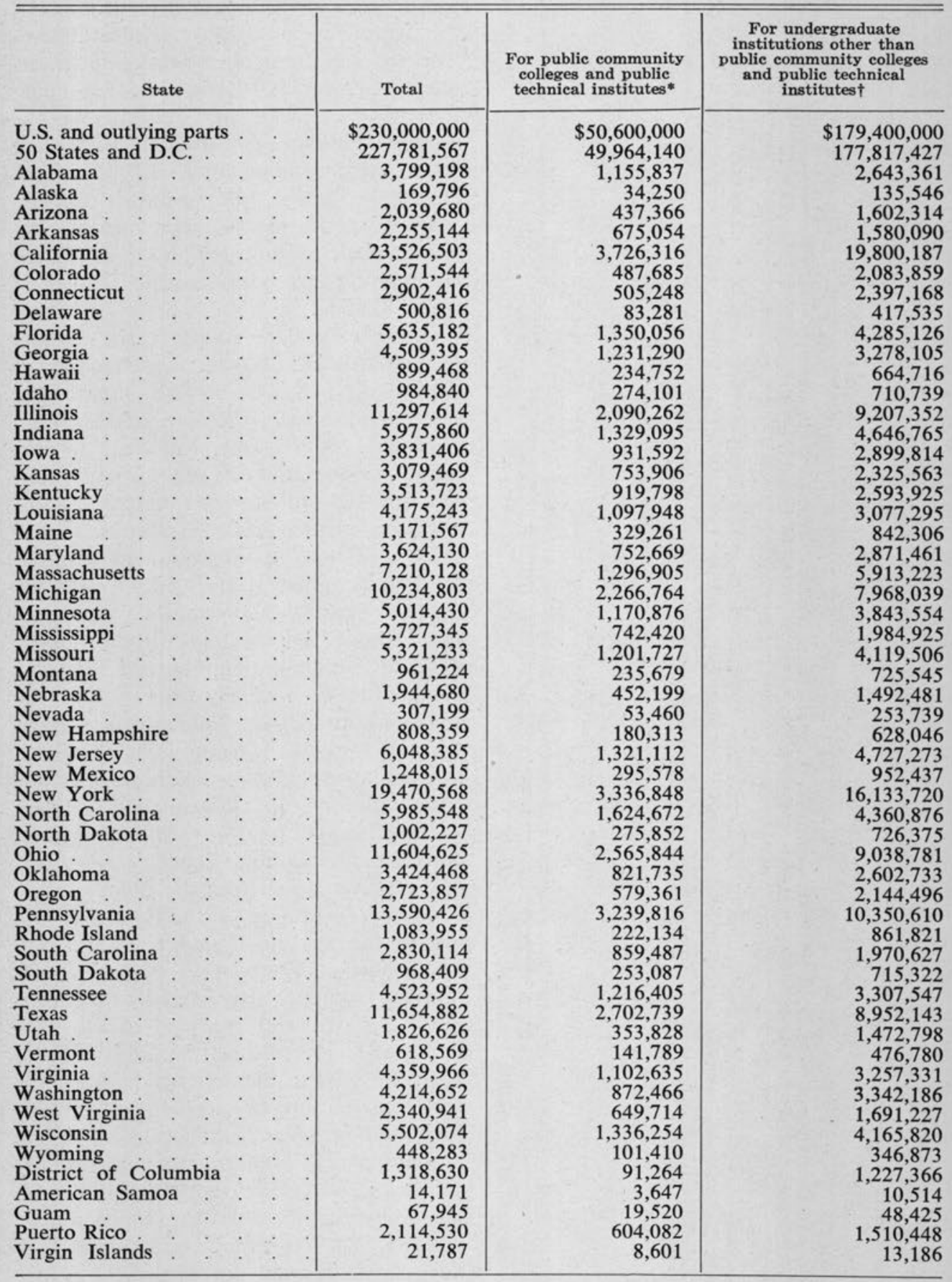


cent of the appropriation. Loans, separately or together with other federal funds, may not exceed 75 per cent of the cost of a project. Interest rate will be equal to that for all federal government obligations plus no less than one-fourth of one per cent.

Excluded from participation in any of the grant or loan provisions of the Act are any facilities intended primarily for events for which admission is charged the general public and athletic facilities, except those to be used for academic instruction in physical education. Also excluded are facilities to be used for sectarian instruction or as a place of religious worship, for a program of a school or department of divinity, or facilities for use by a school of medicine, dentistry, osteopathy, pharmacy, optometry, podiatry, nursing, or public health. The U.S. Commissioner of Education will administer all titles of this Act.

\section{INVENTORY}

A perpetual or continuing inventory, building by building, of existing facilities at higher education institutions was initiated with the "Inventory of College and University Physical Facilities, December 31, 1957." 3 This survey provided data for 85 per cent of the 1,890 institutions of higher education which were operational at that time. It reveals, for example, that as of December 31, 1957 the reporting institutions had nearly twenty-six million net square feet of library space. The space

\footnotetext{
${ }^{3}$ Part 1, "Cost and Finaneing of College and University Buildings, 1951-55," was completed and published in 1959; and Part 2, "Planning for College and University Physical Plant Expansion, 1956-70" was completed and published in 1960. Part 5, "New Colleges and Universities Planned," has not yet been initiated. Part 3, "Inventory of College and University Physical Facilities, December 31, 1957," is in preparation, and Part 4, "College and University Enrollment and Facilities Survey, 1961-65," has just been published.
}

included reading rooms having seating capacity for four hundred forty thousand students or 16.2 per cent of those enrolled during the Fall of 1957. The estimated figure for the period January 1958 through December 1963 is seven million net square feet, making a grand total of thirty-three million net square feet devoted to library space. Estimated seating stations still remain at 16 per cent of student enrollment, Fall 1963.

However, reliable, consistent figures on academic library buildings are difficult to obtain and to verify because of (1) the lack of a central collecting service and (2) the lack of agreement on the differences of terms used in the reporting of library construction. With the undoubted impetus to new academic classroom building and library construction due to the Higher Education Facilities Act, there is a strong need for uniform figures on library construction costs.

Table $7^{4}$ includes all reported library buildings occupied for the first time during 1948-62. Omitted from the list are those library facilities constructed which were not located in a building whose basic function was that of a library.

Due to the reasons mentioned above, Table 7 is both incomplete and inadequate; the primary purpose of the table is to serve as a beginning. Ideally, data for each library building should include construction cost per square foot, total square footage, total volume capacity, seating capacity and equipment costs. As indicated above, for cost figures such data are difficult to secure. There is too much variation on what these terms actually

\footnotetext{
'Sources: College and University Physical Facilities Series: Library Facilities Planning Aids (OE51004-3) ; Progress in the Construction of Higher Education Facilities, 1951-59 (OE-51002); and New Construction and Rehabilitation on College Campuses, 1959-60 and 1960-61 (OE-51002-61).
}

\footnotetext{
* Distributed according to the state products of 1962-63 high school graduates and allotment ratios within limits of .3333 and .6667 .

† One half is distributed according to Fall 1962 enrollment in grades 9-12, and one half is distributed according to Fall 1963 enrollment in institutions of higher ed ucation.
}

NoTE: Some of the data on enrollments and high school graduates are estimated.

SOURCE: Higher Education (January-Febuary 1964), 10. 
TABLE 7

LIBRARY BUILDINGS OCCUPIED FOR THE FIRST Time During 1948-62: Aggregate UNITED STATES*

\begin{tabular}{llll}
\hline \hline STATE AND INSTITUTION & & YEAR $^{\dagger}$ & COST $^{\S}$ \\
\hline Alabama & & & \\
Auburn University &. & 1962 & NA \\
Howard College & $:$ & 1957 & NA \\
Miles College & $:$ & 1961 & 72,000 \\
Oakwood College & $:$ & 1952 & NA \\
Troy State College & $:$ & 1949 & NA
\end{tabular}

Arizona

Arizona State University .

Eastern Arizona Junior College

1961

20,000

Eastern Arizona Junior College

Grand Canyon College

University of Arizona

\section{Arkansas}

Harding College

John Brown University

Little Rock University

Ouachita Baptist College

Southern State College

\section{California}

Antelope Valley Junior College

Bakersfield College

Bakersfield College

California State Polytechnic College

Cerritos College

Chaffey College

Chico State College

Claremont Graduate School (Honnold Library)

Claremont University College (Honnold

Library)

Coalinga College

College of the Holy Names

1958

48,000

1960

1957

1960

12,000

70,000

75,000

College of Marin

College of Notre Dame

College of the Sequoias

Compton College

El Camino College

Fresno State College

Fullerton Junior College

Hartnell College

Humboldt State College

Loma Linda University

Long Beach State College

Los Angeles City College

Los Angeles Harbor College

Los Angeles State College of Applied Arts and

Sciences
1950

1954

1950

1950

1952

NA

NA

NA

NA

NA

1961

1955

1957

1949

1961

1960

1960

1957;

1960

1952

1957

1957

1959

1952

1959

1953

1952

1956

1957

1960

1953

1954

1960

1960

1949

1956

NA

NA

NA

NA

NA

NA

NA

NA

NA

NA
271,000

520,000

556,000

367,000

934,000

550,000

261,000

119,000

272,000

436,000

429,000

$1,070,000$

480,000
Los Angeles Valley

$$
\text { College }
$$

Loyola University of Los Angeles

Marymount College

Monterey Peninsula College

$1960 \quad 638,000$

Oceanside-Carlsbad College 1955

Orange Coast College 1951

Orange Coast College : 1960

Pacific College . . . 1962

Pacific Lutheran

Theological Seminary . 1959

Pacific School of Religion 1957

Pasadena City College . 1949

Porterville College . 1961

Reedley College

Reedley College

1957

1961

Sacramento State College .

San Benito College

1959

1961

San Diego State College

San Fernando Valley State College, Northridge

$19591,433,000$

San Francisco State College

San Jose State College

1961

NA

$1959 \quad 1,341,000$

1957 ;

$1960 \quad 900,000$

Santa Ana College

1959

Santa Barbara City College

Santa Monica City College

1952;

1961

Shasta College

Stanford University

1950

1961

University of California, Berkeley Campus

1949

283,000

NA

625,000

NA

66,000

University of California, Santa Barbara Campus

University of the Pacific

University of Redlands

University of San Diego, San Diego

University of

San Francisco

NA

1954

1956

1958

NA

NA

265,000

$1958 \quad 400,000$

University of Southern

California, Los Angeles

1949

NA

Ventura College

1961

1955

NA

NA

Colorado

Adams State College of Colorado

1955

Colorado College

NA

Colorado School of Mines 1954 ,

Iliff School of Theology . $1956 \quad 220,000$

U.S. Air Force Academy, Colorado Springs

University of Colorado

1959

1961

NA

100,000

Connecticut

Hartford College

Hartford Seminary

Foundation

1961

38,000

St. Joseph College

1960

50,000

$\begin{array}{ll}1961 & 288,000\end{array}$

District of Columbia

Wesley Theological

Seminary

1959

500,000 
Florida

Chipola Junior College . 1959

Florida State University 1960

Gibbs Junior College . 1961

Gulf Coast Junior College 196

Jacksonville University . 1960

Manatee Junior College : 1960

North Florida Junior

College

$1960 \quad 152,000$

Pensacola Junior College . 1960

St. Johns River Junior

College

St. Petersburg Junior

College

University of Miami

University of South

Florida

1961

121,000

$1961 \quad 225,000$

$19623,000,000$

$19611,942,000$

\section{Georgia}

Albany State College . . 195

Berry College 1958 ,

$\begin{array}{ll} & 1961 \\ \text { Emmanuel College } & 1950\end{array}$

Fort Valley State College

Georgia Institute of

Technology

1953

North Georgia College

Savannah State College

Tift College

1959

1954

220,000

400,000

NA

NA

NA

138,000

437,700

NA

\section{Idaho}

Idaho State College

University of Idaho

1954

1957

NA

Illinois

Aurora College

Bradley University

Eastern Illinois University

Elmhurst College

Greenville College

John Crerar Library

(IIlinois Inst. of

Technology)

Knox College

Northern Illinois

University

Northwestern University (Law Library)

Saint Xavier College

Southern Illinois

University

University of Chicago, Law Library

University of Illinois

Wheaton College

1962

1950

1950

1958

1950

$1,500,000$

1962

$1960 \quad 454,000$

1953 NA

$1960 \quad 1,250,000$

1956

NA

1956

$2,000,000$

1960

1959

1953

NA

775,000

NA

Indiana

Anderson College and Theological Seminary

Ball State Teachers College

Concordia Senior College

DePauw University

Earlham College

Evansville College.

Fort Wayne Bible College
1957

NA

$1961 \quad 189,000$

1958

1957

1962

1957

1961
NA

997,000

$1,000,000$

550,000
325,000
Indiana State Teachers

College : . . . 1957

Indiana University . . 1957;

1960

Oakland City College . $1961 \quad 140,000$

Purdue University . . $1958 \quad 8,650,000$

Taylor University . . . 1950 NA

Tri-State College . . . $1951 \quad$ NA

Valparaiso University $\quad 1960 \quad 802,000$

Vincennes University . . $1961 \quad 220,000$

Wabash College . . $1959 \quad 950,000$

Iowa

Briar Cliff College . . $1959 \quad 253,000$

Central College . . $1957 \quad 210,000$

Ellsworth Junior College . $1961 \quad 366,000$

Grinnell College . $19601,024,000$

Loras College . . . . $1961 \quad 525,000$

Marycrest College . . $1959 \quad 262,000$

State University of Iowa . $1949 \quad$ NA

Wartburg College . . $1959 \quad 262,000$

Kansas

Baker University . . . 1961

Central Baptist

Theological Seminary . $1960 \quad 300,000$

Kansas State Teachers College

1951

Kansas Wesleyan Uinversity

1948

$\begin{array}{ll}\text { Ottawa University } & 1956 \\ \text { Sterling College } & 1954\end{array}$

Tabor College . $\quad 1957$

University of KansasMedical Center

1957

University of Wichita . 1962

NA

NA

NA

NA

121,000

NA

NA

\section{Kentucky}

Brescia College

1959

College of the Bible, The 1949

Kentucky State College . 1960

300,000

NA

Southern Baptist Theological Seminary

Transylvania College

University of KentuckyMedical Center

University of Louisville

$1960 \quad 1,412,000$

1954 NA

$1960 \quad$ NA

$19572,000,000$

\section{Louisiana}

Louisiana College

Louisiana State University

Louisiana State University \& A \& M College

Loyola University

McNeese State College

$1955 \quad$ NA

$19583,500,000$

$19592,868,000$

1950 NA

1961535,000

Maine

Bangor Theological

Seminary

1960

300,000

Maryland

Goucher College .
Montgomery Junior

College

1952

NA

Mount St. Agnes College . $1960 \quad 436,000$

140,000

Mount St. Marys College . 1961 
State Teachers College at Bowie

State Teachers College at Towson

State Teachers College, Frostburg

State Teachers College, Salisbury

University of MarylandCollege Park

University of MarylandBaltimore

\section{Massachusetts}

Assumption College
Brandeis University
Gordon College
Harvard University

Pine Manor Junior College

Regis College

Simmons College

University of Massachusetts

Williams College

\section{Michigan}

Flint Junior College

Hillsdale College

Kellogg Community College

Michigan State University of Agriculture and Applied Science

Northern Michigan College

University of Detroit

University of Michigan, The

Wayne State University

Western Michigan University

\section{Minnesota}

Augsburg College and Theological Seminary

Bethel College and Seminary

Carleton College

College of St. Catherine

College of St. Thomas

Concordia College, Moorhead

Gustavus Adolphus College

Macalester College

Mankato State College

Minnesota Bible College

Moorehead College

St. Cloud State College

St. Paul Seminary

University of Minnesota, St. Paul Campus

University of Minnesota, Duluth Campus
$1958 \quad 2,557,000$

$19601,189,000$

$\begin{array}{cc}1956 & \mathrm{NA} \\ 1960 & 2,500,000 \\ 1955 & \mathrm{NA} \\ 1949 ; & \\ 1959 ; & \\ 1961 & 3,200,000 \\ 1957 & 319,000 \\ 1955 & \mathrm{NA} \\ 1961 & 1,789,000 \\ 1960 & 1,694,000 \\ 1957 & 511,000\end{array}$

1961

195

196

$19574,000,000$

1951

1951

NA

NA

$1958 \quad 2,614,000$

1954 NA

$1958 \quad 400,000$

$\begin{array}{lc}1955 & \text { NA } \\ 1950 & \text { NA } \\ 1956 & \text { NA } \\ 1960 & \text { NA } \\ 1960 & 1,515,000 \\ 1956 & \text { NA } \\ 1948 & \text { NA } \\ 1961 & 375,000 \\ 1959 & 1,000,000 \\ 1955 & \text { NA } \\ 1960 & \text { NA } \\ 1952 & \text { NA } \\ 1949 & \text { NA } \\ 1951 & \text { NA } \\ 1953 & \text { NA }\end{array}$

University of Minnesota . 1957;

$19613,620,000$

Mississippi

Blue Mountain College . 1957 NA

Clarke Memorial College . 1956 NA

Coahoma Junior College . 1952 NA

East Central Junior College

$1960 \quad 101,000$

$1960 \quad 385,000$

1957357,000

Mississippi College

Mississippi Delta Junior College

1957

NA

Mississippi State College for Women

Mississippi State

University

1960203,000

Northwest Mississippi Junior College

Perkinston Junior College

Southwest Mississippi Junior College

1950

NA

1953

1957

NA

NA

University of Mississippi

$1961 \quad 115,000$

University of Southern Mississippi

University of Southern Mississippi

1951 NA

1960

NA

1961

850,000

\section{Missouri}

Drury College

National College

$1960 \quad 438,000$

St. Louis University

Southwest Missouri State College

University of Missouri

Washington University

Westminster College

1949 NA

$19593,571,000$

1957 NA

1960 NA

1961;

$19623,700,000$

1951 NA

\section{Montana}

College of Great Falls

1961

Montana State College

Rocky Mountain College

$1960 \quad 240,000$

Nebraska

Concordia Teachers College

Creighton University

Midland College

Municipal University of Omaha

Nebraska State Teachers College, Wayne

University of Nebraska

$1961 \quad 1,250,000$

1953 NA

1956 NA

1956 NA

1957. 230,000

Nevada

University of Nevada, Reno

$1960 \quad 2,612,000$

New Hampshire

St. Anselm's College

1960

NA

New Jersey

Caldwell College for Women

1952 NA 
Centenary College for Women

Douglass College

Fairleigh Dickinson University, Rutherford

Georgian Court College

Glassboro State College

Newark College of Engineering

Newark State College

Paterson State College

Princeton Theological Seminary

Rutgers, The State University

Seton Hall University

Upsala College

$\begin{array}{cc}1954 & \text { NA } \\ 1961 & 1,000,000 \\ 1956 & \text { NA } \\ 1951 & \text { NA } \\ 1955 & \text { NA } \\ 1960 & 1,606,000 \\ 1961 & 140,000 \\ 1956 & \text { NA } \\ 1957 & 1,526,000 \\ 1958 ; & \\ 1961 & 1,475,000 \\ 1953 & \text { NA } \\ 1962 & 1,250,000\end{array}$

New Mexico

Eastern New Mexico University

1953

New Mexico State University of Agriculture, Engineering and Science

New Mexico Western College

University of New Mexico

1952

1958

1952

NA

NA

281,000

NA

New York

Adelphi College

Alfred University

Brooklyn College

Barnard CollegeColumbia University

Canisius College

City College of The City University of New York

Clarkson College of Technology

Colgate University

College of Mount

St. Vincent

Cornell University

D'Youville College

Erie County Technical Institute

Hofstra College

Hunter College

Iona College

Ithaca College

Keuka College

Long Island University

Manhattanville College of the Sacred Heart

Nazareth College

New School for Social Research

New York UniversityBellevue Medical Center

New York University

Orange County Community College

Paul Smiths College of Arts \& Science

NA

1948

1961

1957

$5,666,000$

497,000

1961454,000

$1958 \quad 250,000$

1959 NA

$1960 \quad 654,000$

1953 NA

1952 NA

$1961 \quad 157,000$

1951 NA

1957 NA

$1959 \quad 1,045,000$

1957 NA

$1961 \quad 150,000$
Pratt Institute

1961

Queens College

1954

13,000

Rensselaer Polytechnic Institute

$19611,740,000$

St. Bernardine of Siena College

1955 NA

St. Lawrence University

SUNY, Courtland

SUNY College of

Education, Onconta

SUNY, Geneso

Union College

1960875,000

$19611,100,000$

$1960 \quad 943,000$

$19561,322,000$

1959 NA

\section{North Carolina}

Agricultural and Technical College of North

Carolina

Appalachian State Teachers College

Atlantic Christian College

Brevard College

Davidson College

Elizabeth City State

$$
\text { Teachers College }
$$

Gardner-Webb Junior College Inc.

$9551,000,000$

1960

289,000

Greensboro College

Mars Hill College

North Carolina College at Durham

1950

1948

NA

1960

250,000

1959

23,000

1952

1950

NA

NA

1955 NA

Queens College

1950

NA

Wake Forest College

Western Carolina College

1961

1956

435,000

Wingate College

Woman's College,

University of North

Carolina

1952 NA

1959200,000

1950

NA

North Dakota

North Dakota State

University

1949

NA

State Teachers College, Mayville

State Teachers College, Minot

$1959 \quad 134,000$

1959355,000

State Teachers College, Valley City

University of North

Dakota

1952 NA

$19611,000,000$

Ohio

Antioch College . . $1956 \quad 750,000$

Ashland College ․ . $1961 \quad 350,000$

Baldwin-Wallace College . $1960 \quad 1,107,000$

Case Institute of Technology

Central State College

Defiance College

Hebrew University College - Jewish Institute

Kent State University

Marietta College

Mount Union College

Muskingum College

Our Lady of Cincinnati College
$19612,781,000$

$1960 \quad 440,000$

$1957 \quad 165,000$

$19611,875,000$

$19581,190,000$

$1950 \quad \mathrm{NA}$

$1960 \quad 354,000$

1954 NA
1961855,000 
United Theological

Seminary

University of Akron

University of Toledo

Western Reserve University

Wittenberg University

Youngstown University

\section{Oklahoma}

Cameron State

$$
\text { Agricultural College }
$$

Central State College

East Central State College

Langston University

Murray State Agricultural College

Northeastern State College

Panhandle Agricultural and Mechanical College

University of Oklahoma

Oregon

Northwest Christian

$$
\text { College }
$$

Oregon College of Education

Portland State College

Reed College

Southern Oregon College

University of Portland

Western Evangelical Seminary

NA 450,000

NA

NA

NA

NA

NA

$3,000,000$

1957

295,000

1951

1960

1960

1949

1959

1956

\section{Pennsylvania}

Bucknell University
Crozer Theological
Seminary
Drexel Institute of
Technology
Drexel Institute of
Technology
Elizabethtown College
Gannon College
Grove City College
Gwynedd-Mercy Junior
College

Lafayette College

LaSalle College

Lebanon Valley College

Lycoming College

Messiah College

Pennsylvania Military College

Philadelphia College of Textiles and Science

St. Francis College

St. Vincent College

Seton Hill College

Seton Hill College

State Teachers College, East Stroudsburg

Susquehanna University

Thiel College

University of Scranton

University of Scranton

University of Pennsylvania

NA

NA

NA

1960

150,000

1949 NA

1948 NA

1954 NA

1959

230,000

$19621,800,000$

1952

NA

$1957 \quad 279,000$

1952 NA

1959240,000

1949 NA

1949

1959

1958

1958

1959

NA

1952 NA

1959800,000
Waynesburg College

1955 Wilson College

1961

NA

South Carolina

Anderson College . . . 1956

NA

Citadel

Converse College

1960

Furman University

1951

1958

Newberry College

University of South Carolina

1954

Voorhees School and Junior College

1959

1960

Wofiord College

1949

\section{South Dakota}

Augustana College

1955

General Beadle State

Teachers College

1957

Northern State Teachers College

State University of South Dakota

1950

\section{Tennessee}

Carson-Newman College . 1949

David Lipscomb College . 1948

Freed Hardeman College . 1957 ;

33,000

425,000

Hiwassee College

1961

1955

Memphis State University 1961

Middle Tennessee

State College

1958

Milligan College

1961

Southwestern at Memphis

Tennessee Polytechnic Institute

1953

Tusculum College

1949

1961

University of Tennessee . 1959

NA

108,000

\section{NA}

NA

$19591,500,000$

$1960 \quad 1,521,000$

350,000

712,000

450,000

525,000

$1960 \quad 550,000$

1959239,000

1961745,000

$19624,600,000$

\section{Texas}

Assemblies of God College $1960 \quad 204,000$

Austin Presbyterian

Theological Seminary . 1950

Baylor University . . 1952

Blinn College . . . . 1950

Dallas Theological

Seminary

1960

Decatur Baptist College 1957

East Texas Baptist College 1957

East Texas State College . 1960

Episcopal Theological

Seminary of the

Southwest . . 1956

Hardin-Simmons University 1949

Howard Payne College . 1953

Huston Tillotson College . 1960

Incarnate Word College . 1955

Kilgore College

1957

Lamar State College of

Technology

$1957 \quad 531,000$

North Texas State

College

1960

200,000

North Texas State University

Pan American College

1951

Ranger College

NA

NA

NA

NA

48,000

NA

816,000

NA

NA

NA

249,000

NA

NA

1952

163,000

NA 
Southern Methodist University

Southwestern Union College

Stephen F. Austin State College

Texas College

Texas College of Arts and Industries

Texas Southern University

Texas Wesleyan College

Texas Western College

Trinity University

University of Corpus Christi

University of Houston

University of St. Thomas

Wayland Baptist College

West Texas State College

Wharton County Junior College

NA

1961

246,000

1957

1950

NA

1949

1958

1957

1958

1953

1957

1950

1952

1958

1951

1960

Vermont

Bennington College

Green Mountain College

University of Vermont

1960

1951

1961

435,000

$\mathrm{NA}$

$2,000,000$

\section{Virginia}

Bluefield College

College of William and Mary

Hollins College

Hampden-Sydney College

Lynchburg College

University of Virginia at Charlottesville

Virginia Polytechnic Institute

Virginia State College

Virginia State College

\section{Washington}

Central Washington State College

Gonzaga University

Lower Columbia Junior College

1960

333,000

1959

1955

1961

1954

1960

1955

1959

1960

100,000

NA

390,000

NA

99,000

NA

NA

$1,000,000$

1961

1958

$1,522,456$

630,000

$1959 \quad 122,000$

$1960 \quad 35,000$

University of Puget Sound

Whitman College

Yakima Valley Junior College
1954

1957

NA

413,000

$1958 \quad 201,000$

\section{West Virginia}

Alderson Broaddus College $1958 \quad 285,000$

Bethany College . 1960 NA

Bethany College . . . $1961 \quad 941,000$

Davis \& Elkins College : $1959 \quad 250,000$

Fairmont State College . 1952 NA

West Virginia Wesleyan College

$1953 \quad$ NA

\section{Wisconsin}

Beloit College . . . $1962 \quad 912,131$

Holy Family College . . 1961 1,036,000

University of Wisconsin, Milwaukee

$1961 \cdot 767,000$

University of Wisconsin, Madison

Wisconsin State College \& Institute of Technology Wisconsin State College, Eau Claire

Wisconsin State College, La Crosse

Wisconsin State College, River Falls.

1953 NA

1954 NA

$19611,045,000$

1957814,000

1954 NA

Wyoming

University of Wyoming . $1958 \quad 1,694,000$

- Includes additions and rehabilitation projects.

$\dagger$ When more than one date is given, this denotes separate construction projects.

$\ddagger$ NA $=$ Not available.

$\$$ When more than one year has been reported, the sum of the construction costs has been computed.

mean. It would be extremely helpful if all librarians of recently completed library buildings reported all pertinent data to some central agency, such as the ALA, and if this information were published on an annual basis.

Some specific uses which can be made of Table 7 are (1) to provide a guide to other academic institutions planning to construct library facilities; (2) to provide a base for deriving normative data that may be compared, for evaluative purposes, with data on other similar buildings; and (3) to establish a base line for long range planning. 